\title{
GAMES WITHOUT FRONTIERS: TRENDS IN THE INTERNATIONAL RESPONSE TO INSIDER TRADING
}

\author{
Harvey L. Pitt* and David B. Hardison**
}

\section{INTRODUCTION}

It was a scene emblematic of the Wall Street scandals of the 1980s. Three employees of a leading investment bank were arrested in a carefully orchestrated, pre-dawn "raid" and charged with insider trading. Extensive publicity followed, as commentators opined that the stock markets were rife with trading abuses and in desperate need of reform. After a three-week trial, however, a jury acquitted one of the defendants and the charges against the remaining defendants were eventually dropped.

Before the episode is characterized as an example of excessive prosecutorial zeal by law enforcement authorities in the United States, it should be noted that the foregoing events took place in Melbourne, Australia, not New York City. ${ }^{1}$ Indeed, as the 1980 s drew to a close, they could have occurred in any of a number of the world's leading financial centers.

Although episodic, the recent events in Melbourne illustrate the changing global attitudes toward insider trading. ${ }^{2}$ Not so long ago, insider trading, even if not viewed as a problem confined to U.S. markets, was often considered a concern peculiar to the United States. That is no longer the case. Virtually every country with a major stock market has adopted, or is actively considering, provisions outlawing insider trading. Of particular import, the Council of the European Community has issued a directive that obligates the Member States of the European Economic Community ("EEC") to adopt legislation by June 1, 1992, to ban insider trading. ${ }^{3}$ Countries with developing stock markets likewise have taken, or are in the process of taking,

Copyright $\odot 1992$ by Law and Contemporary Problems

* Partner, Fried, Frank, Harris, Shriver \& Jacobson, Washington, D.C.; former General Counsel (1975-1978), United States Securities and Exchange Commission.

* Associate, Fried, Frank, Harris, Shriver \& Jacobson, Washington, D.C.

1. See Insider Trading Conviction Evades Australian Authorities, Reuters Bus Rep (May 22, 1991); Bill Pheasant, "Not Guilty" Verdict Blow to Regulators, Australian Fin Rev 1 col 2 (Feb 19, 1991); Insider Trading Arrests Spark Debate Over Law's Scope, Intl Sec Reg (March 15, 1989).

2 . The term "insider trading" is generally considered to refer to the wrongful use of material, nonpublic information relating to publicly-traded securities.

3. Council Directive of 13 November 1989 coordinating regulations on insider dealing $89 / 592$, 1989 OJ (L 334) 30 (the "Insider Trading Directive"). The Member States of the EEC are Belgium, Denmark, France, Germany, Greece, Ireland, Italy, Luxembourg, the Netherlands, Portugal, Spain, and the United Kingdom. 
steps to prohibit insider trading as a means of promoting confidence in the integrity of the markets. ${ }^{4}$

The example from Australia reveals another aspect of the international regulation of insider trading: the mere adoption of statutes banning insider dealing does not ensure that authorities will successfully prove violations of the law. Moreover, if the current attitude in the United States is that those found guilty of insider trading should be left "naked, homeless, and without wheels," 5 many countries appear to view the practice as meriting no more than a stiff warning, akin to a traffic ticket. Nevertheless, there are many indications that foreign jurisdictions are beginning to place a higher priority on enforcement.

This article examines, from the perspective of two practitioners, current trends in the global regulation of insider trading. Part II highlights the principal factors that account for the recent enactment or enhancement of insider trading legislation abroad. Part III reviews, in greater detail, the laws of the following countries: Australia, France, Germany, Japan, and Mexico. The common features of these laws are identified, as are the principal areas in which the laws of the various jurisdictions diverge. Part IV identifies lessons that the United States can learn from international insider trading legislation. Finally, Part V suggests that, in light of international trends, multinational corporations and service firms should evaluate the need for firm-wide policies relating to securities trading by employees.

\section{The Sudden Rush to Regulate}

The regulation and prosecution of insider trading in the United States has been, by far, the most vigorous of any country in the world. Even in the United States, however, views regarding the need to prohibit insider trading vary widely. While some economists argue that insider trading promotes an efficient market in securities, ${ }^{6}$ others contend that sound economic reasons justify the aggressive prosecution of insider trading. ${ }^{7}$

The federal courts and members of Congress have repeatedly justified restrictions on insider trading on the grounds that the practice offends basic

4. See, for example, Asia's Emerging Equities Markets, East Asian Exec Rep 22 (Jan 15, 1991) (discussing insider trading laws in Taiwan, South Korea, Malaysia, and Thailand).

5. See Kevin G. Salwen \& Laurie P. Cohen, Getting Tough: SEC Under Breeden Takes a Harder Line on Securities Crime, Wall St J Al col 6 (May 10, 1990).

6. See, for example, Henry G. Manne, Insider Trading and the Stock Market 93-110 (Free Press, 1966); Hsiu-Kwang Wu, An Economist Looks at Section 16 of the Securities Exchange Act of 1934, 68 Colum L Rev 260 (1968).

7. See, for example, Ronald J. Gilson \& Reiner H. Kraakman, The Mechanisms of Market Efficiency, $70 \mathrm{Va}$ L Rev 549, 629 (1984) (concluding that the economic argument in favor of eliminating restrictions on insider trading is "weak"); Joseph A. Grundfest, Remarks to National Investor Relations Institute in New York City (June 20, 1986), reprinted in 18 Sec Reg \& L Rep (BNA) No 26, at 936 (June 27,1986 ) (asserting that " $[t]$ here is an optimal point at which information should be disclosed and it can be inefficient if information is disclosed either too soon or too late"). 
notions of fairness ${ }^{8}$ and jeopardizes public confidence in the integrity of U.S. markets. ${ }^{9}$

In comparison with the United States, where the law of insider trading has developed over the past thirty years, ${ }^{10}$ insider trading in the capital markets of many other nations has been subject historically either to regulations rarely enforced or to no regulation at all. ${ }^{11}$ For example, as recently as 1986 , only three of the twelve Member States of the EEC (Denmark, France, and the United Kingdom) prohibited insider trading. ${ }^{12}$ While some nations have no history of regulating insider trading, other countries consider insider trading, as defined in the United States, to be a respectable activity traditionally engaged in by directors and officers. ${ }^{13}$

Given the longstanding indifference to insider dealing in many nations, the rush to prohibit insider trading, or to enforce dormant laws against the practice, is all the more striking. Three principal factors appear to motivate most countries to crack down on insider trading: competitive pressures, international enforcement efforts, and technological developments.

\section{A. Competitive Pressures}

The internationalization of the world's capital markets is, by now, taken for granted, as technological advances have contributed to astonishing growth in

8. See, for example, Chiarella v United States, 445 US 222, 245 (1980) (Burger, CJ, dissenting) ("Chiarella ... misappropriated-stole to put it bluntly-valuable nonpublic information entrusted to him in the utmost confidence ... [and] then exploited his ill-gotten informational advantage by purchasing securities in the market.").

9. See, for example, Insider Trading Sanctions Act of 1983, Hearings before the Subcommittee on Securities of the Senate Committee on Banking, Housing, and Urban Affairs, 98th Cong, 2d Sess 1 (1984) (remarks of Sen. D'Amato) ("the integrity of the market is the victim [of insider trading] since it is seriously undermined").

10. The Securities and Exchange Commission ("SEC" or "Commission") adopted Rule 10b-5, its principal weapon against insider trading, in 1943, after members of the SEC's staff were advised that a corporate insider was purchasing shares of a company's stock without disclosing a material fact that would cause the market price to rise. See Milton V. Freeman, Administrative Procedures, 22 Bus Law 891, 922 (April 1967). While a federal court implied a private remedy under Rule 10b-5 for insider trading in Speed v Transamerica Corp., 71 F Supp 457, 458 (D Del 1947), the law of insider trading in the United States truly began to develop with the seminal decision of the SEC in In re Cady, Roberts $\hat{\sigma}^{\circ}$ Co., 40 SEC 907 (1961).

11. Dennis W. Carlton \& Daniel R. Fischel, The Regulation of Insider Trading, 35 Stan L. Rev 857, 860 (1983).

12. Note, Subject Matter Jurisdiction Over Transnational Securities Fraud: A Suggested Roadmap to the New Standard of Reasonableness, 71 Cornell L Rev 919, 936 (1986) (authored by David Michaels).

13. See, for example, Larry Zaglin, Insider Trading in Japan: A Challenge to the Integration of the Japanese Equity Market Into the Global Securities Market, 1987 Colum Bus L Rev 419, 421 (noting that "[t]he cultivation of close ties to sources of information in order to obtain advance notice of significant corporate developments has long been considered an important service offered by Japanese brokerage firms"); André Tunc, A French Lawyer Looks at American Corporation Law and Securties Regulation, $130 \mathrm{U}$ Pa L Rev 757, 762 (1982) (tipping of inside information considered "a social duty . . . expected of relatives and friends" in France); Craig Forman, Old World Traditions Include Insider Trading," Wall St J Cl col 3 (Feb 8, 1989) (quoting an EEC official as stating that, in some European countries, "it is considered a very normal consequence, and not a bad thing, to profit from information [you] happen to have"). 
cross-border transactions. ${ }^{14}$ As markets have become more international in character, they have also grown more competitive. Since rampant insider trading in a nation's markets often impairs the attractiveness of that market to foreign participants, competitive pressures may lead to adoption of laws prohibiting insider dealing or to stricter enforcement of existing laws.

At heart, these pressures are not radically different in character from the domestic pressures that have led countries to ban insider trading. ${ }^{15}$ In international parlance, insider trading is often condemned as inconsistent with the need for "transparent" markets, markets with procedures and trade standards that are fair and comprehensible to foreign investors. ${ }^{16}$

Moreover, countries that do not appear to be taking steps to prohibit insider trading frequently receive harsh criticism, often from countries with competing securities markets. Within the EEC, there is a widely-held perception that a handful of financial centers will dominate the European markets in the years ahead. ${ }^{17}$ It is, therefore, not surprising that the British press has seized upon recent reports on insider trading in Germany as evidence of that country's loosely supervised markets, ${ }^{18}$ or that, in response, German bankers have voiced support for additional insider trading legislation and stronger enforcement. ${ }^{19}$

14. For example, the volume of U.S. equity securities purchased and sold from abroad increased several-fold, from $\$ 25.6$ billion in 1977 to $\$ 481.9$ billion in 1987 . See Problems with the SEC's Enforcement of U.S. Securities Laws in Cases Involving Suspicious Trades Originating from Abroad, HR Rep No 100-1065, 100th Cong, 2d Sess 3 (1988) ("Suspicious Trades").

15. Pressures to curb insider trading often surface when a broader cross section of society elects to participate in a country's stock market. See, for example, Joseph Blum, The Regulation of Insider Trading in Germany: Who's Afraid of Self-Restraint?, $7 \mathrm{Nw}$ J Intl L \& Bus 507, 513 (1986) (pressures for restrictions on insider trading in Germany arose after World War II, when German citizens were encouraged to invest in stock markets); Party's Over in India As Boom Goes Bust, Assoc Press (Sept 28, 1987) (emergence of middle-class investors in India led to demands for insider trading regulations and other market reforms).

16. See, for example, Japan Approves Stricter Rules to Combat Insider Trading, Washington Post F5 col 2 (Feb 1, 1989) (quoting Japan's Finance Minister as stating that "regulations on insider trading are indispensable for sound development of our country's securities market by increasing the sense of fairness and transparency in the stock market"); Europeans Are Steering for Market Reform, LA Times D9 col 1 (Aug 17, 1988) (quoting French Finance Minister Pierre Beregovoy as emphasizing the need for "more transparency for the markets . . . to protect the safety of small investors"). See also Policy Statement of the United States Securities and Exchange Commission, Regulation of International Securities Markets 11 (Nov 1988) (asserting that “[i]nvestors will seek out markets they perceive as fair and honest" and that "[c]ountries that do not have prohibitions against insider trading ... risk becoming havens for illegal activities").

17. See, for example, Ferdinand Protzman, Insider Trading Scandal Grows, NY Times D6 col 3 (July 23, 1991) (discussing efforts in Germany to promote Frankfurt as site for the proposed European central bank); Stephen Greenhouse, An Old Club Transformed, NY Times D6 col 4 (July 23, 1991) (noting that recent steps to upgrade securities enforcement in France have distinguished Paris Bourse from "rival European markets in Milan or Madrid")

18. See, for example, Katherine Campbell, Spotlight Falls on German Trading Practices, Fin Times 124 (July 3, 1991) (concluding that German trading practices "fall well short of those appropriate to an aspiring international centre," and quoting a former Deutsche Bank employee as stating that "[a]s far as trading ethics go, this is still virtually a third world country").

19. See, for example, Insider Trading in Germany, Wall St J A6 col 1 (July 24, 1991) (noting that opposition to central supervisory authority "has crumbled among Germany's powerful banks"); Ferdinand Protzman, Insider Trading Scandal Grows, NY Times D6 col 3 (July 23, 1991) (quoting 
Efforts underway within the EEC, and elsewhere, to reduce barriers to takeovers may also spur efforts to regulate insider trading, as more active markets for corporate control are often associated with higher levels of insider trading. In the United States, for example, the frenzied market for takeovers during the 1980s, combined with the growth in the trading of options and other financial instruments, was often cited as having created new opportunities for unscrupulous traders to profit from inside information. ${ }^{20}$

Hostile takeovers remain largely an unknown phenomenon in many foreign countries, where a panoply of legal, structural, and cultural barriers to unsolicited changes in corporate control exist. ${ }^{21}$ Companies in the United Kingdom and the United States, where comparatively few structural restrictions exist on takeovers, have long objected to the competitive disadvantages they face when pursuing foreign acquisitions. In response to such concerns, the EEC has proposed a directive on takeovers that would establish bidding procedures and place limits on the defensive measures which target companies may employ. ${ }^{22}$ Despite these developments, substantial barriers to an active market for corporate control are likely to persist in many countries for the foreseeable future. To the extent that the number of foreign mergers and acquisitions increases ${ }^{23}$ and barriers to takeovers erode, however, the opportunities for insider trading and the pressures for effective insider trading laws can be expected to mount.

\section{B. International Enforcement}

The internationalization of the securities markets not only facilitates global investing, but also creates new opportunities for insider trading. For example, unscrupulous traders may seek to trade through accounts in jurisdictions with secrecy and blocking laws that purport to preclude the

Rudiger von Rosen, Managing Director of the Frankfurt Stock Exchange, as stating that "[e]veryone here wants laws making insider (rading a criminal offense").

20. SEC and Insider Trading, Hearing before the Subcommittee on Oversight and Investigations of the House Committee on Energy and Commerce, 99th Cong, 2d Sess 47 (1986) (written statement of former SEC Chairman John S.R. Shad).

21. See generally 1 Barriers to Takeovers in the European Community App C (1989) (study prepared by Coopers \& Lybrand for the United Kingdom Department of Trade and Industry summarizing technical and structural barriers to takeovers in the EEC's Member States).

22. See Amended Proposal for a Thirteenth Council Directive on Company Law, Concerning Take-Over and Other General Bids, art 8, 1990 OJ (C 240) 7 (the "Takeover Directive"). For a general discussion of the Takeover Directive, see Lois Moore, The EC's Proposed Takeover Directives, NYU L J 1 (May 28, 1991). Recent reports suggest that the Takeover Directive has met with strong opposition from Germany, the Netherlands, and the United Kingdom, and that its eventual adoption is uncertain. See, for example, Andrew Hill, Brussels Worried About Slow Passage of 1992 Laws, Fin Times I3 (Sept 13, 1991) (concluding that the Takeover Directive is unlikely to be adopted in 1991). Countries that are not members of the EEC have also taken tentative steps toward eliminating some of their restrictions on the foreign ownership of shares. See, for example, Christione de Senarclens, Switzerland: Revision of Corporation Law, 19 Intl Bus L 271 no 5 (May 1991) (discussing proposals in Switzerland to eliminate blanket restrictions on the foreign ownership of registered shares of $S$ wiss companies).

23. See, for example, David J. Berger, European MEA Activity Is On An Upward Swing, Manhattan Law 12 (April 1991) (predicting continued growth in mergers and acquisitions activity in continental Europe). 
disclosure to foreign agencies of information regarding their accounts. ${ }^{24}$ Internationalization also may result in insider trading if foreign investors persist in engaging in conduct that, although permitted in their home markets, violates the laws of other countries. ${ }^{25}$

The United States has responded to these trends by increasing the resources devoted to the investigation and prosecution of transnational insider trading cases. ${ }^{26}$ In turn, the SEC's vigorous application of insider trading laws to transactions originating abroad has given foreign countries an incentive to examine their own law enforcement efforts. ${ }^{27}$ Furthermore, although the United States cannot dictate the securities laws of other nations, the SEC has exerted pressure on countries to prohibit insider dealing and to provide the Commission with information in insider trading cases. ${ }^{28}$

Switzerland's adoption of legislation criminalizing insider trading in 1988 provides one example of a nation responding to pressures from the United States. ${ }^{29}$ For years prior to the enactment of article 161 of the Swiss Penal Code, the SEC had sought, with mixed success, to obtain evidence from Swiss banks during investigations of foreign-based trading. ${ }^{30}$ Although in some cases the SEC succeeded in obtaining information pursuant to the terms of a Memorandum of Understanding negotiated with the Swiss government in $1982,{ }^{31}$ the lack of a statutory ban on insider trading in Switzerland limited the SEC's ability to take advantage of other law enforcement treaties between

24. See Harvey L. Pitt, David B. Hardison \& Karen L. Shapiro, Problems of Enforcement in the Multinational Securities Market, 3 Selected Articles on Federal Securities Law 322, 329-33 (American Bar Association, section of Business Law, 1991).

25. See, for example, Lori Hawkins, Mexico Faces Problems with Insider Trading, Reuters Bus Rep (May 16, 1991) (discussing current efforts in Mexico to educate securities professionals about the insider trading laws of Mexico and the United States following an insider trading case filed against a Mexican executive in connection with the proposed takeover of a U.S. corporation).

26. See Reauthorization for the Securities and Exchange Commission, 1992-94, Hearing before the Subcommittee on Securities of the Senate Committee on Banking, Housing, and Urban Affairs, 102d Cong, lst Sess 22 (July 25, 1991) (testimony of Richard C. Breeden, Chairman of the United States Securities and Exchange Commission, requesting further increases in resources available to the SEC for international enforcement and assistance initiatives).

27. See, for example, Insider Trading Probes Having Global Domino Effect, Chicago Trib N13 (March 5, 1989) (quoting Professors Louis Loss of Harvard and William Tyson of the University of Pennsylvania as stating that Wall Street insider trading scandals caused many foreign governments to toughen standards).

28. See, for example, Houle, Survey of National Legislation Regulating Insider Trading, 9 Mich YB Intl Legal Stud 209 (1988) (foreign governments are enacting, or considering the adoption of, insider trading legislation, "[i]n part as a response to pressure from the U.S. government").

29. Swiss Law Prohibiting Insider Trading, Schweizerisches Strafgesetzbuch (StGB), Swiss Penal Code, art. 161.

30. See, for example, SEC $v$ Katz, [1986-1987 Transfer Binder] Fed Secur L. Rptr (CCH) ๆ 92,867 at 94,226 (SD NY Aug 7, 1986) (alleged insider trading in securities of RCA through the Geneva branch of the Union Bank of Switzerland); SEC v Certain Unknown Purchasers of the Common Stock, and Call Options for the Common Stock of Santa Fe Int'l Co., [1981-1982 Transfer Binder] Fed Secur L Rptr (CCH) 998,323 at 92,025 (SD NY Oct 26, 1981) (suspected insider trading through Swiss banks prior to announcement of proposed merger between Santa Fe and Kuwait Petroleum Corp.); SEC v Banca Della Svizzera Italiana, 92 FRD 111 (SD NY 1981) (investigation of orders placed by Swiss bank to purchase securities on the New York and Philadelphia Stock Exchanges).

31. Memorandum of Understanding Between the Government of the United States of America and the Government of Switzerland (Aug 31, 1982) ("Swiss MOU"). In one insider trading case, the SEC obtained disclosure of the identity of a Swiss banking customer under the Swiss MOU within six 
the United States and Switzerland. In particular, the Treaty between the United States and the Swiss Confederation on Mutual Assistance in Criminal Matters ("Swiss-U.S. Treaty") 32 provides that assistance is available only with respect to offenses deemed criminal in both countries. Because the SEC was allowed to gather evidence under the Swiss-U.S. Treaty only if it could demonstrate that inside information had been tipped to third parties, ${ }^{33}$ the "dual criminality" requirement severely curtailed the SEC's ability to obtain information during the preliminary stage of an investigation. ${ }^{34}$ Switzerland's adoption of article 161, with the strong encouragement of the United States, eliminated this impediment to the SEC's efforts to obtain evidence from Swiss banks. ${ }^{35}$ Similarly, Japan is reported to have strengthened its prohibitions on insider trading largely at the urging of the United States. ${ }^{36}$

In addition, the United States exerts indirect pressure on other countries to curb insider trading abuses. First, the SEC continues to bring high-profile enforcement actions involving foreign-based insider trading. ${ }^{37}$ Second, the

months after first approaching the SBA with a request. See SEC v Katz, Fed Secur L Rptr (CCH) I 92,867 at 94,226 .

32. Mutual Assitance in Criminal Matters, [1976] 27 UST Part 2 (1973).

33. Under Swiss law prior to 1988 , a corporate insider did not violate the law by trading securities on the basis of material, nonpublic information solely for his or her own account. The disclosure of confidential business information to third parties, however, gave rise to potential liability under article 162 of the Swiss Penal Code. See Pitt, Hardison \& Shapiro, Problems of Enforcement at 346 (cited in note 24 ).

34. The SEC's experience in the Santa Fe case, which occurred before Switzerland criminalized insider trading, illustrates this point. The SEC first submitted a request for assistance under the treaty on March 22, 1982. On January 26, 1983, the Swiss Federal Court denied the request, on grounds that it failed to demonstrate that the facts, as alleged, would have violated Swiss law. See 22 ILM 785 (1983). The SEC renewed its request on July 27, 1983, at which time it introduced additional facts suggesting that the conduct under investigation constituted a violation of thencurrent Swiss law. After the SEC made this showing, the Swiss Federal Court granted the Commission's request in an unpublished opinion dated May 16, 1984, although the actual production of evidence was delayed an additional nine months as a result of further appeals of the court's decision to grant access. See Michael D. Mann, Anne H. Sullivan \& Teresa A. Koncick, Current Issues in International Securities Law Enforcement 43-45 (Jan 10, 1987) (paper prepared for American Bar Association's Institute on International Litigation and Arbitration).

35. See Note, Swiss Law Prohibiting Insider Trading: Its Impact on Switzerland and the United States, 16 Brooklyn J Intl L 379, 391 (1990) (authored by Catherine E. Donahue) (noting that "each treaty or agreement between Switzerland and the United States lay the groundwork for the Swiss law criminalizing insider trading").

36. See, for example, Michael Hughes, Insider Trading Like Polygamy_Depends Where You Do It, Reuters Bus Rep (March 27, 1989) (quoting Japanese broker as stating that Japan upgraded criminal penalties for insider trading in response to pressure from the United States). The ability of the United States to force other countries to prohibit insider trading and provide information to the SEC should not be exaggerated. Indeed, Congress has criticized the Commission for allegedly failing to investigate suspected insider trading originating abroad where "the United States does not have an information-sharing agreement and/or the Commission has had problems obtaining information ... in the past due to bank secrecy and blocking laws." Suspicious Trades at 18 (cited in note 14).

37. See, for example, SEC v Certain Purchasers of Common Stock and Call Option Contracts for the Common Stock of Contel Corp., No 90 Civ 4636 (CSH) (SD NY July 13, 1990) (SEC alleged insider trading immediately prior to public announcement of proposed acquisition of Contel by GTE Corp. through foreign banks and brokerage firms); SEC v Marcour, No 90 Civ 1930 (JPG) (D DC June 14, 1990) (SEC alleged insider trading in stock of Apollo Computer Inc. by German resident employed by Apollo's wholly-owned German subsidiary); SEC v Godfrey, No 90 Civ 1962 (RJW) (SD NY March 22, 1990) (SEC alleged insider trading by manager of Inter-Continental Hotels subsidiary of Grand Metropolitan Plc. in connection with the British company's 1988 acquisition of Pillsbury); SEC $v$ 
SEC often discovers information suggesting breaches of the laws of other countries during its investigations of suspected violations of the U.S. securities laws. Where the SEC has provided compelling evidence of insider trading or other market abuses to foreign authorities, those authorities have had a strong incentive to investigate and file charges. ${ }^{38}$ Third, the SEC has supported legislation to authorize the Commission to conduct investigations on behalf of foreign regulators in the United States, ${ }^{39}$ and has continued to negotiate new information-sharing agreements with foreign governments. ${ }^{40}$ In short, much of the pressure brought to bear on foreign governments by the SEC consists of "regulation by example."

\section{Technological Developments}

Conventional wisdom holds that rapid advances in telecommunications, combined with the multiple listing of securities and the resulting potential for twenty-four-hour trading, vastly increase the opportunities for insider trading. ${ }^{41}$ As long as surveillance mechanisms lag behind technological developments, the conventional wisdom is undoubtedly correct. ${ }^{42}$

Advances in technology, however, also open the door to more effective surveillance techniques. In particular, a number of foreign stock exchanges have recently acquired sophisticated trading systems that include electronic audit trails. ${ }^{43}$ Technological innovations thus facilitate the efforts of

Finacor Anstalt and Certain Purchasers of Call Option Contracts for the Common Stock of Combustion Engineering, Inc., No 89 Civ 7667 (JMC) (SD NY Nov 16, 1989) (SEC alleged insider trading by Liechtensteinbased entity in connection with acquisition of Combustion Engineering by Swiss-based company).

38. For example, in 1987 the SEC alerted the Department of Trade and Industry to potential violations of the laws of the United Kingdom involving Guinness Plc.'s takeover of Distillers Co., based on information obtained during the investigation of Ivan Boesky in the United States. See, for example, Terry Garrett, Mounting a Counterattack to U.K. Trading Abuses, Mergers \& Acquisitions 64, 64-66 (July/Aug 1987). More recently, the SEC is believed to have set in motion an investigation by French authorities of suspected insider trading in the stock of U.S.-based Triangle Industries immediately prior to its acquisition by Pechiney S.A., a state-owned metals group. See, for example; Insider Trading Probes Having Global Domino Effect, Chicago Trib N13 (March 5, 1989) (discussing the COB's probe of pre-announcement trading in Triangle shares).

39. See, for example, $\S 6$ of the Insider Trading and Securities Fraud Enforcement Act of 1988, Pub L No 100-704, 102 Stat 4677 (1988) (creating new $\$ 21$ (a)(2) of the Exchange Act authorizing the SEC to conduct investigations in the United States of persons and institutions suspected of violations of foreign securities laws).

40. See Michael D. Mann \& Joseph G. Mari, Developments in International Securities Law Enforcement 62-78 (February 13, 1990) (paper prepared for Practising Law Institute's Securities Enforcement Institute discussing MOUs and other information-sharing agreements).

41. See, for example, Note, Icarus and His Waxen Wings: Congress Attempts to Address the Challenges of Insider Trading in a Globalized Securities Market, 23 Vand J Transnatl L 99, 105 (1990) (authored by John Thornell Thomas).

42. See, for example, Exchange Act Rel No 21958, 32 SEC Docket 1241, 1252 (April 18, 1985) (noting that " $[t]$ here are few surveillance mechanisms in place to safeguard the integrity of securities trading conducted simultaneously in multiple international markets"); Craig Forman, Old World Traditions Include Insider Trading, Wall St J Cl col 3 (Feb 8, 1989) (stating that "[c]omputerized trails on trading activity are rare [in Europe] because in many European markets, prices still are written on blackboards and trades are scribbled on scraps of paper").

43. See, for example, Mexico to Purchase Vancouver Stock Exchange Computerized Trading System, PR Newswire (July 22, 1991) (announcing sale of computerized trading system to Mexican Stock Exchange that would include electronic linkage between trading and surveillance functions); Don 
regulators to detect violations that previously went unobserved. While it remains to be seen whether regulators abroad will take full advantage of their new capabilities, technological developments should permit foreign authorities to enforce laws against insider trading more vigorously.

\section{III}

\section{Survey of Foreign Insider Trading Laws}

This section profiles the laws of five countries to illustrate the range of approaches that different jurisdictions have adopted to address perceived insider trading abuses. It examines the laws of two European countries (France and Germany), two Pacific-region countries (Australia and Japan), and one developing nation (Mexico).

The discussion of each country addresses the circumstances that gave rise to restrictions on insider dealing, the content of the insider trading prohibitions, and the enforcement of the laws. The analysis focuses on the laws that specifically prohibit insider trading, although in theory other laws might be invoked to combat the practice. In comparison to the United States, however, where insider trading is prosecuted primarily under a general antifraud provision, ${ }^{44}$ other nations generally have opted to enact specific prohibitions on insider dealing.

\section{A. Australia}

Australia has regulated insider trading since the early 1970s. Prosecutors have brought numerous cases under the insider trading laws, but have been hindered by Australia's complex statutory scheme, as well as by judicial reluctance to enforce the statute. ${ }^{45}$ In June 1991, Australia revised its insider trading statute and increased the penalties for insider dealing. ${ }^{46}$

1. Background. As in the United States, concern with insider dealing in Australia has intensified during periods of active takeover activity and economic prosperity. ${ }^{47}$ Legislation restricting insider trading was first adopted in 1970,48 but failed to stem criticisms of the extent of insider trading in Australia. ${ }^{49}$ More detailed insider trading legislation was adopted in 1980,50 but it failed to provide a significant deterrent to insider trading; a

Lewis Kirk, West Germany: Capital Markets Take Up the Global Challenge, Institutional Investor S1 (Jan 1990) (discussing development of new centralized data center for Germany's eight stock exchanges).

44. Securities Exchange Act of 1934, § 10(b), 15 USC \& 78j(b) (1988) ("Exchange Act").

45. Roman Tomasic, Insider Trading Law Reform in Australia, Company \& Sec LJ 121 (June 1991).

46. Corporations Legislation Amendment Act 1991 (effective date Aug 1, 1991).

47. Legislative Panel Calls for Insider Trading Law Changes, Intl Sec Reg Rep 7 (Dec 6, 1989).

48. Section $75 A$ of the Securities Industry Act 1970 No 351201 (NSW).

49. Tomasic, Insider Trading Law Reform at 121 (cited in note 45) (discussing study published by the Senate Select Committee on Securities and Exchange in 1974).

50. See $\S 128$ of the Securities Industry Act 1980 ("SIA"). This section was subsequently recodified as $\$ 1002$ of the Corporations Act of 1989. See James D. Cox, An Outsider's Perspective of Insider Trading Regulation in Australia, 12 Sydney L Rev 455, 463 (March 1990). 
1988 survey of market participants concluded that "the incidence of insider trading in Australia ranges between 'not uncommon' and 'widespread.' " 51

Reflecting continued concerns that widespread insider trading in Australia was making the nation's markets unattractive to foreign investors and was discouraging small investors from investing in securities, 52 in February 1989, the Attorney General requested that the House of Representatives Standing Committee on Legal and Constitutional Affairs (the "Griffiths Committee") study the extent of insider trading and other forms of market manipulation in Australia. ${ }^{53}$ The committee issued its report in October 1989, which concluded that "corporate spiders" were able to engage in insider trading in Australia "with little risk of prosecution or conviction." 54 The report proposed a number of revisions to Australia's insider trading law, including a broader definition of an "insider" and increased penalties for insider dealing. The Federal Government largely endorsed the committee's recommendations and enacted revised legislation in June 1991.

2. Content of Insider Trading Law. As amended in June 1991, the Corporations Law prohibits an insider-a person who possesses material, nonpublic information concerning a company's securities-from engaging in securities transactions, if he or she knows or should know that the information is not generally available and might have a material effect on the price or value of the securities if made public. ${ }^{55}$ The act also makes it illegal for the insider to procure other persons to trade on his behalf. ${ }^{56}$ In addition, the law contains an "anti-tipping" provision: an insider shall not directly or indirectly communicate material, nonpublic information concerning a company's securities to another person if the insider knows or should know that the other person would likely engage in securities transactions or procure a third person to buy or sell securities on his behalf. ${ }^{57}$

Prior to the June 1991 amendments, the Australian statute did not permit the imposition of liability on corporations for insider trading. As amended, however, the act provides that a "body corporate" will be deemed to possess information that is known by an officer of the corporation and that he or she came to possess in the course of official duties. ${ }^{58}$ The statute further provides that a body corporate is presumed to be aware of information that an officer

51. Roman Tomasic \& Brendan Pentony, Insider Trading, 14 Legal Serv Bulletin 3, 4 (Feb 1989).

52. Id.

53. The principal exchange in Australia is located in Sydney, although exchanges are also located in each of the other five state capitals (Adelaide, Brisbane, Hobart, Melbourne, and Perth).

54. Griffiths Committee, Fair Shares for All: Insider Trading in Australia (Oct 1989).

55. Section 1002G of the Corporations Law. Section 1002B of the Corporations Law sets forth the circumstances in which information will be deemed "generally available." Section 1002C, in turn, provides that a reasonable person should expect that information will have a material effect on the price or value of a company's securities if "the information would, or would be likely to, influence persons who commonly invest in securities in deciding whether or not to subscribe for, buy or sell the first-mentioned securities."

56. Id at $\$ 1002 G(2)(b)$.

57. Id at $\$ 1002 \mathrm{G}(3)$.

58. Id at $\S 1002 \mathrm{E}$ (a). 
of the corporation knows, or ought reasonably to know, because he or she is an officer of the corporation. ${ }^{59}$ These provisions, however, do not prevent a company from engaging in securities transactions if it employs "Chinese Wall" procedures which insulate the purchaser or seller of securities at the corporate level from price-sensitive information, 60 or if the securities transactions relate to a corporate transaction with another company. ${ }^{61}$

The Corporations Law contains several affirmative defenses. A person accused of insider trading may avoid liability by establishing that the information received was broadly disseminated. 62 In addition, a defendant may seek to establish that the person on the opposite side of the transaction knew, or ought reasonably to have known, the price-sensitive information before entering into the transaction. ${ }^{63}$

Violations of the insider trading law ${ }^{64}$ by individuals are punishable by fines of $\$ 200,000$ (Australian) and/or imprisonment for five years. The penalty for violations by corporations is currently $\$ 1$ million. ${ }^{65}$

3. Enforcement. Under the statutory scheme that existed in Australia during the $1980 \mathrm{~s}$, responsibility for the enforcement of the insider trading laws was divided between the National Companies and Securities Commission (the "NCSC") and the Corporate Affairs Commissions of the various states.66. Although its name suggests otherwise, the NCSC reported to the state governments. The agency had both a small staff and limited resources; during its 1988 fiscal year, the NCSC had a budget of less than \$6 million and approximately 85 employees. ${ }^{67}$ In January 1991, the NCSC was replaced by the Australian Securities Commission (the "ASC"), which reports to the federal government and operates with a substantially larger budget. ${ }^{68}$

In the past, however, the primary obstacle to the effective enforcement of the insider trading prohibitions in Australia has not been the size of the NCSC's budget, but rather the technical requirements of the statute and the hostile reception of Australian courts to attempts by prosecutors to bring

59. Id at $\S 1002 \mathrm{E}(\mathrm{b})$

60 . Id at $\$ 1002 \mathrm{M}$.

61. Id at $\S 1002 \mathrm{Q}$. The provision is apparently intended to clarify that a corporation intending to acquire another corporation or otherwise acquire or dispose of its securities will not be deemed to have engaged in insider trading.

62. Id at $\$ 1000 \mathrm{~T}(2)(\mathrm{a})$.

63. Id at $\$ 1000 \mathrm{~T}(2)(\mathrm{b})$.

64. Id at $\$ 1002 \mathrm{G}$.

65. A separate provision of the Corporations Law authorizes a private right of action on behalf of any person who enters into a prohibited transaction with an insider, if such person can establish the difference between the price paid or received for the securities and the price which would have prevailed had the information been generally available. See id at $\$ 1013(3)-(4)$. This provision predates the June 1991 amendments to the Corporations Law and has rarely been invoked by private investors. See Cox, Outsider's Perspective at 476-77 (cited in note 50).

66. Cox, 12 Sydney L Rev at 475 (cited in note 50).

67. Id at 475 .

68. Kevin Brown, Australian Watchdog Given Teeth, Fin Times I25 (June 21, 1991) (reporting that the ASC will have a budget ten times as large as the NCSC). 
insider trading cases. Indeed, not a single criminal conviction for insider dealing was secured during the 1980 s. ${ }^{69}$

The 1991 revisions to the Corporations Law simplified the law in several important respects. ${ }^{70}$ It is too early to conclude that these amendments will lead to successful prosecutions in Australia for insider dealing, although recent developments suggest that the pieces may finally be in place for more effective enforcement. ${ }^{71}$

\section{B. France}

Although insider trading has enjoyed a long tradition in France, restrictions on insider trading and the penalties for insider dealing have increased over the past two decades. The most significant development in recent years was the enhancement of the investigative powers of the Commission des Operations de Bourse (the "COB"), the French counterpart to the SEC.

1. Background. The origins of the current French legislation on insider trading are found in the ordinance of September 28, 1967 (the "Ordinance"), which created the $\mathrm{COB}$ and, as part of a broader set of disclosure-oriented initiatives, required that directors and officers of French corporations report their securities transactions to the COB. As the COB's small staff was unable to process the insider reports that the Ordinance required to be filed, the $\mathrm{COB}$ advocated legislation to replace the reporting requirement with a

69. See, for example, Australian Insider Trading Bill To Be Introduced in Parliament Soon, $23 \mathrm{Sec}$ Reg \& L Rep 771 (BNA) (May 17, 1991) (noting that "no successful criminal prosecution of an insider trading case has occurred in Australia thus far"). Two recent cases illustrate the hurdles faced by prosecutors in Australia. In :989, the Corporate Affairs Department in Western Australia charged Terrence Wheeler with insider trading under $\S 128$ of the SIA. Wheeler was managing director of Genanalysis, a company which analyzed mineral samples for other companies. After analyzing samples that contained high grades of gold that had been supplied to Genanalysis by Parmelia Resources N.L., Wheeler purchased shares of Parmelia and an affiliated company. Following public disclosure of the mineral analysis, Parmelia's stock price "went for a spectacular run." Tomasic, Insider Trading Law Reform at 123 (cited in note 45). The Western Australian Crown Solicitor's Office dismissed the prosecution, however, on the grounds that there was no evidence to support the conclusion that Wheeler was "connected" with Parmelia, as then required by section 128 . Id at 124 .

In a more recent case, the government charged Charles Claudianos with illegally tipping his brother John with respect to the shares of Rancoo, a company listed on the Hobart and Melbourne exchanges, shortly before Rancoo announced that it was entering into a joint venture with Claudianos's employer to develop vaccines. Id at 124-25. Rancoo's share price increased from $\$ 1.05$ to $\$ 2.50$ during the ten-day period after the joint venture was announced. Id. The magistrate in the case dismissed the prosecution on the grounds that there was no direct evidence that Charles Claudianos had tipped his brother. On appeal, the Supreme Court of the Australian Capital Territory held that the circumstantial evidence was sufficient to establish liability but nevertheless declined to reinstate the prosecution. Myers v Claudianos, (1990) 2 ACSR 73.

70. Most significantly, liability for insider trading is no longer limited to persons "connected with a body corporate," as $\$ 128$ of the SIA had required. See $\$ 1002 \mathrm{G}$ of the Corporations Law.

71. In addition to the establishment of the ASC and the adoption of new insider trading legislation, the Australian Stock Exchange ("ASX") has upgraded its surveillance capabilities. See J. Berry \& G. Yanco, Enter the ASX Computer Police: How an Electronic Eye Spots the Villains, J Sec Inst of Australia 2-5 (March 1990) (discussing more vigorous monitoring of suspected insider trading on the ASX). 
prohibition against insider trading. ${ }^{72}$ The French Parliament enacted legislation along the lines recommended by the COB in $1970 .{ }^{73}$ Since its adoption, article 10-1 has been amended on several occasions in response to perceived weaknesses in its operation.

2. Content of Insider Trading Law. As amended, the Ordinance prohibits insiders from trading in securities while in possession of privileged information not yet disclosed to the public. The basic prohibition applies to trading by two categories of persons: directors, officers, and key executives of any public company and their spouses; and persons who possess privileged information "as a result of the exercise of their profession or responsibilities."74

The Ordinance governs trading by insiders while in possession of "privileged information on the prospects or situation of an issuer or to future movements in the price of a security." Although the Ordinance does not contain a materiality requirement, $\mathrm{COB}$ regulations define "privileged information" as "non-public, specific information ... which, if made public, could have an impact on the price" of the security. ${ }^{75}$ In addition, the courts have required prosecutors to establish that the information in question is "precise, specific and certain."76

When first adopted in 1970, the Ordinance did not address the tipping of privileged information or tippee liability. Article 10-1 has since been amended, however, to prohibit insiders from "knowingly allowing" third parties to trade on privileged information. In addition, insiders may not communicate privileged information to third parties "outside the normal purview of [their] profession or functions." COB regulations supplement these provisions by providing that persons shall not trade on the basis of privileged information that originated either directly or indirectly from an insider. ${ }^{77}$

The Ordinance initially failed to impose penalties on corporations for insider trading. Amendments to article 10-1 in 1983 addressed this disparity, in part, by providing that corporate officers of a legal entity that engages in a prohibited transaction are criminally liable for the violation. Neither the

72. Barry A. K. Rider \& H. Leigh Ffrench, The Regulation of Insider Trading 235 (Oceana, 1979).

73. Law No 70-1208 of December 23, 1970 (adding new article 10-1 to the Ordinance).

74. Article 10-1 of the Ordinance (as amended by Law No 83-1 of Jan 3, 1983, art 35). Regulations adopted by the COB have construed this language broadly, as have the French courts. See Reglement No 90-08 Relatif a L'Utilisation D'Une Information Privilegiee, JO 8600 (July 20 , 1990) ("Regulation 90-08'). See also Docouloux-Favard, Dix ans de jurisprudence et d'activite de la commission des operations de bourse, 104 GP 419 (Sept/Oct 1984) (noting that the Ordinance had been deemed applicable to temporary administrators or bankruptcy receivers, stock brokers and bank employees, a government official who obtained information from a corporation in his official capacity, and an architect who observed the chairman of the company for which he was working meet with the chairman of another corporation and surmised that a rumored joint venture would take place).

75. Regulation 90-08, art 1 .

76. See, for example, Compagnie Francaise d'Entreprise, 1978 JCP II, No 18789) (Cour d'appel, May 26, 1977).

77. Regulation 90-08, art 5 . 
Ordinance nor regulations adopted by the $\mathrm{COB}$, however, impose liability on corporations for insider trading violations by their employees. ${ }^{78}$

Violations of article 10-1 of the Ordinance may result in criminal penalties. The Ordinance authorizes fines ranging from FF 6000 to 10 million, or ten times the profits made, and/or terms of imprisonment ranging from two months to two years. Tipping violations are subject to fines of FF 10,000 to 100,000 and/or. terms of imprisonment ranging from one to six months. ${ }^{79}$

3. Enforcement. The $\mathrm{COB}$ is responsible for investigating suspected violations of the ordinance, although public prosecutors handle actual criminal prosecutions. In the past, the $\mathrm{COB}$ has been constrained by its limited resources. ${ }^{80}$ The COB's investigatory powers were also narrowly circumscribed. ${ }^{81}$ As a result of these limitations, the COB referred only a small fraction of the matters under investigation to public prosecutors. ${ }^{82}$ While successful prosecutions have led to fines, few, if any, defendants have actually been imprisoned for insider trading, although others have received suspended sentences. ${ }^{83}$

Two highly-publicized insider trading investigations in 1988 prompted a reexamination of the COB's limited enforcement powers. First, the SEC advised the $\mathrm{COB}$ of substantial trading activity originating in France three days prior to the announcement that Pechiney S.A., a state-owned metals group, was launching a friendly takeover of U.S.-based Triangle Industries. ${ }^{84}$

78. Commentators have characterized the lack of secondary liability for corporations under French law as a "serious deficiency." Rider \& Ffrench at 235 (cited in note 72).

79. See Law No 89-531 of August 2, 1989, arts 7-8 (amending article 10-1 of the Ordinance). In addition, pursuant to authority granted in 1989, the $\mathrm{COB}$ is authorized to impose a fine on persons who engage in practices which have the effect of distorting the operation of the market or jeopardizing investors' equal access to information and investment opportunities. The fine may not exceed the greater of FF 10 million or 10 times the profit realized as a result of the violation. See id at art 5 (creating new article 9-2 of the Ordinance).

80. For example, in 1985, the COB employed but seven investigators, who were responsible not only for handling suspected cases of insider trading, but also for reviewing financial statements and monitoring the mutual fund industry. Robert Bordeaux-Groult, Problems of Enforcement and Cooperation in the Multinational Securities Market: A French Perspective, 9 U Pa J Intl Bus L 453, 455 (1987).

81. For example, the $\mathrm{COB}$ could not subpoena documents from the general public but only from stock market professionals. While the agency could summon any person suspected of having information relevant to a pending inquiry to provide testimony, it had no power to sanction individuals who refused to comply with its requests. Id at 457.

82. The COB conducted approximately 350 investigations between 1983 and 1988 but made only 30 referrals for prosecution. See Astrid R. Baumgardner, SEC/COB Agreements: The French Perspective, NY L J 5 (June 21, 1990). Even where the COB made referrals, the high standard of proof required in criminal cases created a substantial hurdle. In the absence of substantial, direct evidence that the persons accused of insider trading had received privileged information prior to trading, the courts were reluctant to impose criminal penalties. See, for example, 1986 GP 459 (Trib gr inst May 13, 1986) (acquitting defendants who traded in securities of defense contractor Thomson C.S.F. shortly before announcement that company had signed major contract with Saudi Arabia); $1976 \mathrm{JCP}$ II, No 18496 (Trib gr inst March 17, 1976) (acquitting, for lack of sufficient proof, corporate secretary who sold shares of issuer's securities five days before board meeting at which company's poor financial condition was discussed).

83. James Lightburn, Insider Trading in France, Intl Fin L Rev 23, 24 (Jan 1988).

84. Thomas Kamm, Four Firms Are Said To Be Scrutinized In Alleged Insider Trading In Triangle, Wall St J C14 col 5 (Dec 22, 1988). 
In addition, allegations of insider trading arose in connection with the attempted takeover of Societé Generale, a prominent French bank, by persons associated with the government. ${ }^{85}$

Although the COB referred criminal charges to the public prosecutors in both cases, the Triangle and Societé Generale inquiries led to demands for the French government to increase the COB's resources and investigatory powers. As a result, the $\mathrm{COB}$ now has an annual budget of approximately $\mathrm{FF}$ 100 million and a staff of 200, which pales in comparison with the SEC, but represents a major increase over prior years. ${ }^{86}$ In addition, amendments to the ordinance have improved the COB's ability to subpoena documents and testimony from persons believed to have information relevant to an inquiry, ${ }^{87}$ and have authorized fines of FF 15,000 to 2 million and/or a term of imprisonment ranging from fifteen days to two years for persons who obstruct a $\mathrm{COB}$ investigation. ${ }^{88}$ The amendments also empower the $\mathrm{COB}$ to issue cease-and-desist orders to enjoin violations of its regulations, as well as to levy civil fines against persons found to have violated COB regulations. ${ }^{89}$

Recent indications suggest that the COB is beginning to take advantage of its new powers. In 1990, the COB conducted seventy-five investigations (compared with fifty-two during 1989), approximately one-third of which involved allegations of insider dealing. Of fifteen cases referred to public prosecutors, nine involved insider trading. ${ }^{90}$

\section{Germany}

According to one tongue-in-cheek observer, the German approach to insider trading illustrates "the Bauhaus principle of 'Less Is More." 91 For the past twenty years, Germany has eschewed governmental regulation, relying instead upon a system of voluntary guidelines to address insider dealing. The release of the EEC Insider Trading Directive, combined with a series of recent stock market scandals, however, has led Germany to the verge of adopting legislation formally banning insider trading.

1. Background. Several explanations have been offered for the lack of concern with insider trading in Germany. One scholar observed that the role of the equity markets in Germany has historically been limited, and that only sophisticated investors able to protect their own interests without

85. E.S. Browling, France Wants 5 To Be Charged In Insider Case, Wall St J Al1 col 4 (May 31, 1990).

86. Looking at Clouseau, The Economist 92 (May 19, 1990).

87. Law No 89-531 Regarding the Security and Transparency of the Financial Market, art 2 (Aug 2 , 1989) (amending article 5B of the Ordinance).

88. Id art 6 (amending article 10 of the Ordinance).

89. Id art 5 (incorporated as articles 9-1 and 8-1 of the Ordinance).

90. More Than Half of Investigations Involve Foreign Business, COB Says, Intl Sec Reg Rep 3 (July 1, 1991) (noting that COB's annual report stated that largest category of cases referred to public prosecutors involved insider trading).

91. Presiegfried H. Elsing \& Donna Shook-Wiercimok, New German Insider Trading Regulations, Intl Fin L Rev 30 (Oct 1988) (cartoon accompanying article). 
governmental intervention have participated in the stock markets. ${ }^{92}$ Officials have also suggested that the dearth of mergers and acquisitions in Germany presents fewer opportunities for insider trading than are available in other industrial nations.93 ${ }^{93}$ Others have claimed that legal restrictions on insider trading would be impractical in light of the typically close relationships between German banks and corporations.94 According to one official, "American-style rules against insider trading would miss the point" because "an organized insider situation" exists in Germany. 95

Despite claims that prohibitions on insider trading would be unnecessary or impractical, demands for restrictions on insider dealing have surfaced periodically in Germany. In the late 1960s, prompted by concern over the low level of participation by German citizens in the stock market, the Federal Minister of Economics established a commission of stock exchange experts to study reforms. Although the panel concluded that restrictions on insider trading would play "a significant role" in promoting "confidence in the orderly transaction of stock exchange business," it declined to recommend the adoption of civil or criminal penalties for insider trading. ${ }^{96}$ Instead, at the behest of the business community, the government endorsed a series of voluntary insider trading Guidelines (the "Guidelines") as an alternative to federal legislation. ${ }^{97}$ The Guidelines were adopted in 1970 and amended in 1976 and 1988.

2. Content of Insider Trading Guidelines. In their current form, the Guidelines do not have the force of law. Instead, German banks and stock corporations agree to require their employees (and other agents with access to inside information) to submit to the Guidelines as a term of employment. ${ }^{98}$

92. See, for example, Blum, $7 \mathrm{Nw} \mathrm{J}$ Intl L \& Bus at 513 (cited in note 15).

93. Paul Johnston, West Germany's Gentlemen's Approach to Insider Dealing, Reuters Bus Rep (Dec 21 , 1987) (quoting Chief Executive of the West German Federation of Stock Exchanges).

94. Under Germany's system of "universal banking," banks provide retail banking, commercial lending, investment banking, and stock brokerage services to their customers. In addition, banks own significant stakes in German companies and are often represented on their supervisory (nonmanagement) boards. See 2 Barriers to Takeovers at 13 (cited in note 21 ).

95. West Germany's Gentlemen's Approach to Insider Dealing, Reuters Bus Rep (Dec 21, 1987).

96. Blum, $7 \mathrm{Nw} \mathrm{J}$ Intl L Bus at 516 (cited in note 15) (quoting and translating Insider handelsRichtlinien (Insider Trading Guidelines), reprinted in Rodrian Bruns, Wertpapier und Börse $\$ 436$ (Schmidt, 1976) (“Guidelines").

97. Klaus J. Hopt, The German Insider Trading Guidelines-Spring-Gun or Scarecrow?, 8 J Comp Bus \& Cap Mkt L 381,382 (1986).

98. Stock corporations that have not agreed to abide by the Guidelines are identified with a special notation on the quotation lists published by the German exchanges. See Federation of German Stock Exchanges' Insider Rules 5 (July 1988). 
Under the Guidelines, persons deemed "insiders"99 are not permitted to engage in transactions in "insider securities" 100 based on the use of "insider information" obtained in the course of their employment. ${ }^{101}$ "Insider information" is defined as "knowledge of circumstances not yet disclosed or publicly known which could affect the valuation of the insider securities." 102

Insiders are also prohibited from procuring others to trade on their behalf or passing insider information to persons who are not insiders, unless required by law or a valid business purpose. ${ }^{103}$ Tippees, however, are not themselves subject to the Guidelines unless they have agreed to abide by the Guidelines as a condition of employment.

3. Enforcement. Suspected violations of the Guidelines are investigated by a five-member Board of Inquiry established by each of the German stock exchanges. ${ }^{104}$ The conduct of investigations is governed by procedural rules adopted shortly after the Guidelines were introduced. ${ }^{105}$ In the event that a violation is found, the Board of Inquiry informs the corporation, as well as the Federal Minister of Economics. The sole remedy authorized is the disgorgement of any trading profits to the corporation. If the person found to have violated the Guidelines refuses to disgorge the profits, the corporation must bring an action in court for breach of contract, unless a "material reason" exists not to file suit. ${ }^{106}$

While investigations under the Guidelines are not uncommon, they virtually never result in findings of wrongdoing. ${ }^{107}$ The Frankfurt Board of Inquiry did conclude in 1986, however, that a member of the supervisory board of AEG AG, an electronics concern, had engaged in insider trading by purchasing 700 shares of AEG prior to the public announcement of its acquisition by Daimler-Benz AG. The Board characterized the infraction as a

99. "Insiders" include the members of the supervisory board of the corporation (as well as its affiliates), shareholders owning more than $25 \%$ of the corporation's stock, and employees and agents of the corporation who obtain access to insider Information in the course of their employment or agency relationship. Guidelines $\S 2(1)$ (cited in note 96). In recognition of the close relationships between banks and German corporations, banks and their employees are also considered "insiders" if they receive insider information in the course of a lending relationship or while providing advisory services. Id.

100. "Insider Securities" include, among other things, stocks, convertible bonds, warrants, and subscription rights issued by domestic corporations and admitted for official quotation or trading on the regulated market on a domestic stock exchange. Id at $\$ 2(2)$.

101. Id at $\S 1$.

102. A comment to the Guidelines states that it is irrelevant whether the corporation intended that the information be treated as confidential. Instead, the sole consideration is whether the information is available to the general public. Id at comment 2 to $\S 2$.

103. Id at $\$ 1$.

104. Although Germany's principal stock exchange is located in Frankfurt, exchanges are also located in Berlin, Bremen, Dusseldorf, Hamburg, Hanover, Munich, and Stuttgart.

105. Guidelines $\$ 3$ (cited in note 96) (providing that suspected violations shall be investigated under the procedural rules established at the stock exchanges pursuant to the Guidelines and separate rules for traders and advisers).

106. Id at $\S \S 4(1)-(2)$.

107. According to one report, the Frankfurt Stock Exchange has generally conducted five to ten insider trading investigations annually, although there is reason to believe that the number of investigations is increasing. Sweeping Out the Stables, The Economist 15 (Aug 31, 1991). 
"minor violation" and required the insider to disgorge his profits to AEG. More significant than the characterization of the board member's conduct, however, was the Board's failure to detect any other insider trading, despite the fact that, in the ten days prior to the announcement of Daimler-Benz's offer, the price of AEG's stock surged twenty-eight percent on active trading. ${ }^{108}$

The lack of effective enforcement of the Guidelines to date has led one German legal expert to conclude that they are a "toothless device."109 Indeed, Germany's reluctance to adopt formal prohibitions on insider dealing has placed it squarely out of step with other members of the EEC. In particular, the EEC's proposal of the insider Trading Directive in 1987 met strong criticism in Germany, where government and stock market officials sought to preserve the system of self-regulation. ${ }^{110}$

Perhaps less by choice than by compulsion, however, Germany is moving toward legislation banning insider trading. As other Member States of the EEC moved to implement the Insider Trading Directive even before it was adopted in final form, Germany dropped its opposition to the proposal. ${ }^{111}$ Moreover, in the wake of a recent scandal involving the trading practices of German banks, authorities have called not only for the passage of insider trading legislation, but also for the creation of a federal agency charged with enforcing the insider Trading Directive and other EEC initiatives. ${ }^{112}$

\section{Japan}

Most observers of the Japanese securities markets-Japanese and nonJapanese alike-agree that insider trading has long been tolerated. International criticism, however, as well as recent insider trading and other stock market scandals prompted the Japanese Diet to amend the Securities

108. Blum, $7 \mathrm{Nw} \mathrm{J}$ Intl L \& Bus at 526-27 (cited in note 15). Indeed, under the Guidelines, only insiders connected with AEG were prohibited from trading; Daimler-Benz executives and board members were free to buy AEG shares before the public announcement.

109. Id at 524 (citing address by University of Berlin Professor Michael Will).

110. See Johnston, Reuters Bus Rep (cited in note 93).

111. See Norma Cohen, Stephen Fidler \& Tim Dickson, City Anger at EC insider Proposals, Fin Times 24 (May 12, 1989).

112. Katharine Campbell, German Stock Scam Prompts Tighter Rules, Fin Times 3 (Sept 19, 1991) (quoting board member of the Frankfurt Stock Exchange). The recent inquiry in Germany was triggered by an anonymous letter to Effecten Spiegel, a financial publication, accusing an equity warrants trader at Deutsche Bank with insider dealing. See, for example, Frank Kane, Tumbrils Roll at Deutsche: Insider Dealing Probes at Germany's Top Bank Send Shivers Through Frankfurt, Daily Telegraph 30 (July 7,1991 ). The investigation quickly ripened, however, into a broader examination of frontrunning and stock manipulation by traders at German banks, who allegedly were allowed by their employers to engage in such practices as a means of increasing their compensation. See Katharine Campbell, Deutsche Bank to Tighten Rules for Traders, Fin Times 25 (July 25, 1991). The resulting negative publicity has apparently inspired Germany to redouble its efforts to enact legislation banning insider trading by June 1992, which is the deadline established in the insider Trading Directive. See German Insider Trading: Behind the Times, The Economist 86 (July 13, 1991). 
and Exchange Law ("SEL")"13 in May 1988 to define insider trading and impose penalties.

1. Background. Japanese attitudes toward investing and the structure of the Japanese securities markets help explain the laissez-faire approach to insider trading in Japan. As in other countries profiled in this article, securities transactions in Japan traditionally have been considered risky investments appropriate only for sophisticated investors with close ties to the securities markets. ${ }^{14}$ Brokers and other market professionals, in turn, were expected to seek "inside information" as a basic service to their institutional customers. ${ }^{115}$

Other features of the Japanese markets also make shares of stock in Japanese companies susceptible to price manipulation and insider dealing. In particular, Japan's business community is built around keiretsu-horizontal and vertical business alliances in which the participating companies have interlocking directors and own substantial blocks of each others' shares. ${ }^{116}$ Because members of a keiretsu generally hold shares of affiliated companies on a long-term basis, the public "float" of many Japanese companies is limited and, therefore, subject to manipulation. ${ }^{117}$ Indeed, an entire lexicon has developed in Japan to refer to the shares of companies whose stock prices are manipulated by brokerage firms to benefit select customers. ${ }^{118}$

Nevertheless, Japan concluded in 1988 that a formal ban on insider trading was necessary. ${ }^{19}$ Two events appear to have triggered the adoption of the amendments to the SEL that year. First, in mid-1987, it was disclosed that a bank had sold 337,000 shares of Tateho Chemical Industries Co., a company to which it had made substantial loans, one day before Tateho announced large losses. Following an investigation, the Osaka Securities Exchange found that the bank had violated no securities laws. This

113. See Chieko Takeshita \& Kazumi Okamura, Japan's Securities Markets: Regulation of Insider Trading, 12 E Asian Exec Rep 8 (Nov 14, 1990).

114. See, for example, Note, Regulation of Insider Trading in Japan, 89 Colum L Rev 1296, 1296 (1989) (authored by Tomoko Akashi).

115. See Larry Zaglin, Insider Trading in Japan: A Challenge to the Integration of the Japanese Equity Market Into the Global Securities Market, 1987 Colum Bus L Rev 419, 421 (1987).

116. Carla Rappoport \& Sally Solo, Why Japan Keeps on Winning, Fortune 76 (July 15, 1991).

117. See, for example, Allan Sloan, Japan's Rigged Market: The Beginning of Some Beautiful Friendships, Washington Post D3 (July 2, 1991). On the other hand, the fact that a majority of the shares of many Japanese corporations are in friendly hands insulates the companies from the threat of a hostile takeover. The absence of hostile takeovers in Japan has also been cited as a factor that accounts for the lack of concern with insider trading in Japan. See Zaglin, 1987 Colum Bus L Rev at 421 (cited in note 115 ).

118. See, for example, Sloan, Washington Post at D3 (cited in note 117) (Japanese brokerage firms invest unlucky but favored customers in "ambulance stocks" and politicians in "election stocks.").

119. The Ministry of Finance ("MOF") and the stock exchanges had previously advised securities professionals and listed companies to take steps to avoid insider trading. See Note, 89 Colum L Rev at 1301 (cited in note 114). Of particular import, the Tokyo Stock Exchange had warned listed companies that insider trading by corporate insiders might violate article 58 of the SEL, a general antifraud provision which resembles Rule 10b-5 under the Exchange Act. Nevertheless, no prosecution for insider trading under article 58 has ever taken place in Japan. See Takeshita \& Okamura, 12 E Asian Exec Rep at 8 (cited in note 113) (stating that the failure to apply article 58 to insider trading "reflected the ... public attitude of tolerance toward the practice"). 
conclusion, however, only reinforced the views of many observers that the MOF and the exchanges were not yet prepared to curb insider abuses. ${ }^{120}$ Second, as foreign interest in the Japanese markets increased, so did criticism that insider trading denigrated the integrity and highlighted the transparency of Japan's securities markets. ${ }^{121}$

In response, the Securities and Exchange Council, an advisory body to the MOF, established a subcommittee in October 1987 to examine alleged insider abuses. Based on the recommendations contained in the Council's February 1988 report to the MOF, the Japanese Diet adopted legislation to amend the SEL by criminalizing insider trading in May $1988 .{ }^{122}$

2. Content of Insider Trading Laws. The Japanese laws against insider trading are set forth in articles 190-2 and 190-3 of the SEL and supplemented by MOF ordinances. The primary prohibition against insider trading is article 190-2; article 190-3 addresses more specifically illegal trading in connection with tender offers.

Article 190-2 provides that a "corporate insider"123 who obtains knowledge of a "material fact" 124 related to a company listed for trading on a Japanese exchange shall not engage in transactions in the company's securities until the fact is made public. There is no requirement that the insider act with a fraudulent intent. Article 190-2 also prohibits trading by "tippees" who obtain knowledge of material facts directly from a corporate insider. The act of tipping does not violate the statute; article 190-2 is violated only if the tippee purchases or sells securities based on the information provided. ${ }^{125}$ In general, subsequent tippees will not be deemed to have violated article $190-2$, unless the first tippee is considered a conduit, in which case a remote tippee may be treated as the original tippee. ${ }^{126}$

Article 200 of the SEL sets forth the penalties for violating articles 190-2 and 190-3. Violations of either article are punishable by a prison term of up

120. Note, 89 Colum $L$ Rev at 1302 (cited in note 114).

121. Takeshita \& Okamura, 12 E Asian Exec Rep at 8 (cited in note 113).

122. Id at 20. The effective date of the legislation was April 1, 1989. Id.

123. "Corporate insiders" are defined to include (1) corporate officers, agents and employees; (2) significant shareholders who obtain knowledge while exercising their statutory right to inspect the corporation's books; (3) persons with supervisory authority over the corporation; (4) other persons with contractual relationships with a corporation who obtain knowledge in the exercise of their contractual duties; and (5) in the event that the person referred to by category (2) or (4) is a corporation, the corporation's officers or agents. SEL art 190-2(1).

124. In general, a material fact relates to one of the following: (1) a strategic decision made by corporate management; (2) the occurrence of certain events over which management has limited control, such as damage arising from a natural disaster; (3) material (and previously undisclosed) changes in the corporation's sales, operating profits, or net income meeting criteria to be established by the MOF; or (4) other material facts "relating to the management, business, or property of the company, which may have significant influence on the investment decisions of investors." SEL art 190-2(2). Article 190-2 authorizes the MOF, by ordinance, to establish that facts which otherwise fall within categories (1) or (2) would not be material to the investment decisions of investors. See, for example, MOF Ordinance No 10 (Feb 3, 1989).

125. SEL art 190-2(3).

126. Note, 89 Colum L Rev at $1314 \mathrm{nl} 164$ (cited in note 114) (citing statement by the Director of the MOF Securities Bureau). 
to no more than six months or a fine of not more than 500,000 . In addition, article 207 subjects a corporation to an identical fine where a representative of the corporation violates article 190-2 or 190-3 "in connection with the business operations or property of the corporation."

3. Enforcement. Responsibility for the enforcement of Japan's insider trading laws is divided between the MOF and the public prosecutors. The MOF has traditionally been viewed as a champion of Japanese securities firms rather than as a public watchdog. The fact that the MOF prefers to issue advice to market participants through informal communications, as opposed to published rules or interpretations, reinforces this perception abroad. ${ }^{127}$

The MOF's investigatory powers are limited. Article 154 of the SEL authorizes the MOF to order a securities exchange or a company listed on the exchange to submit reports or data that reflect upon the health of the exchange, but falls short of conferring the power to subpoena documents or compel testimony for use in investigations of suspected insider trading. Investigations conducted by public prosecutors are also hampered by a lack of cooperation from the securities industry. ${ }^{128}$ However, the MOF has drafted rules governing cooperation and information-sharing with prosecutors in insider trading cases. The MOF also has a separate inspection section within its securities bureau to monitor suspicious stock transactions. ${ }^{129}$

Since the adoption of articles $190-2$ and $190-3$ in 1988, only a handful of cases enforcing the insider trading laws have arisen. In September 1990, a former president of a finance company was fined $¥ 200,000$ (approximately $\$ 1,581$ ) in connection with insider trading in the shares of a company listed on the Tokyo Stock Exchange. ${ }^{130}$ More recently, Japanese prosecutors began investigating the sale of 22,000 shares of Macross Corporation by a senior managing director shortly before the public announcement that another Macross officer had entered a fictitious profit into the company's accounts. ${ }^{131}$ Although prosecutors have been criticized for targeting individuals on the "financial fringe" for prosecution, ${ }^{132}$ observers in Japan claim that the cases have prompted Japanese corporations to encourage compliance with the new laws. ${ }^{133}$

While Japan may have hoped that the adoption of articles 190-2 and 190-3 would be viewed favorably abroad, the limited number of enforcement cases

127. See Alan L. Beller, John Palenberg \& Richard M. Levine, Japanese Capital Markets: A Summary of Selected Regulatory Developments 2 (March 15, 1991) (paper prepared for Euromoney seminar on Japanese Capital Markets and Corporate Finance; characterizing MOF's regulatory philosophy as "opaque" rather than "transparent").

128. Takeshita \& Okamura, 12 E Asian Exec Rep at 21 (cited in note 113).

129. See, for example, LDP Approves Draft Bill on New Financial Watchdog Body, Kyodo News Service (Nov 26, 1991) (MOF has separate inspection sections within its Securities, Banking and International Finance bureaus).

130. Id.

131. Robert Thomson, Offices Raided in Japanese insider Trading Probe, Fin Times 4 (May 2, 1991 ).

132. Id.

133. See Takeshita \& Okamura, 12 E Asian Exec Rep at 21 (cited in note 113). 
brought to date suggests that "informal market practices remain far more important than written market regulations." 134 Moreover, the scandal in the summer of 1991 involving the reimbursement of major customers against losses by Japan's largest brokerage firms has further tarnished the international image of the Japanese securities markets. ${ }^{135}$ These events led to demands for the creation of an independent agency modeled after the SEC to monitor the Japanese securities markets, ${ }^{136}$ although these proposals were rejected in favor of a semi-autonomous monitoring board subject to MOF oversight. ${ }^{137}$ It is possible, but by no means certain, that the establishment of this new board will lead Japanese officials to crack down more severely on insider trading in the future.

\section{E. Mexico}

Mexico adopted legislation prohibiting insider trading in 1983. The law has not been vigorously enforced, but prosecutions stemming from the 1987 stock market collapse and the negotiation of a memorandum of understanding with the SEC in 1990 indicate that stricter enforcement of the law is contemplated.

1. Background. Although Mexico's stock exchange, La Bolsa de Valores de Mexico, S.A. ("Bolsa"), is the largest exchange in Latin America, Mexico's current securities laws date back only to 1975 . In that year, Mexico enacted the Securities Market Law ("SML"), which overhauled the existing statutory scheme. ${ }^{138}$ The statute prohibited issuers from engaging in conduct designed to manipulate stock prices, but did not originally contain a general antifraud provision or prohibit insider trading. ${ }^{139}$ In 1983 , article 16 bis was added to address the recurring problem of insider trading. ${ }^{140}$

2. Content of Insider Trading Law. Article 16 bis prohibits persons with access to "privileged information" regarding an issuer from engaging in securities

134. James Sterngold, Japan: Informal Code Rules Markets, NY Times D6 col 2 (July 23, 1991).

135. See, for example, Ted Holden, et al, Japan Cleans House-Again, Business Week 26 (July 8 , 1991) (stating that "the latest scandal offers fresh evidence that the bureaucrats still have a long way to go to clean up the inbred Japanese markets").

136. See Securities Watchdog Viewed With Suspicion, Japan Times 5 (Sept 30, 1991) ("Many securities market analysts . . . believe the establishment of an autonomous agency is the best way to prevent future abuses."); SDP Calls for Independent Securities Watchdog, Japan Econ News Wire (Sept 1, 1991) (noting the introduction of draft legislation by the Social Democratic Party in the Japanese Diet to establish an independent agency responsible for monitoring the Japanese securities markets).

137. See Japan-Watch-Dog for Securities Market, World Accounting Rep (Oct 1991) (noting that the MOF had successfully lobbied against recommendations by Prime Minister Kaifu's government to establish an independent agency modeled after the SEC).

138. Samuel Wolff, An Overview of Mexico's Capital Markets and Securities Regulation, in Doing Business in Mexico \$ 62.04[1] (Matthew Bender 1990) ("Overview of Mexico").

139. SML art $14, \S \mathrm{VII}$.

140. See, for example, Jonathan Fuerbringer, Waiting for the Other Shoe in Mexico, NY Times C13 col 3 (July 1, 1990) (analysts assert that purchasing shares on the Bolsa can be risky due to insider trading). 
transactions on their own behalf or on behalf of third parties. 141 "Privileged information" is defined as information "originating from the issuer" that is not publicly available and, if known, might have an influence on the market price of the issuer's securities or those of another company. ${ }^{142}$

The ban on trading set forth in article 16bis applies to corporate officers, shareholders owning more than ten percent of an issuer's capital stock, and persons who have obtained access to privileged information while providing advisory or business services to an issuer. 143 Persons affiliated with brokerage houses, specialist units, stock exchanges, and depositories are also prohibited from trading if they receive access to privileged information regarding an issuer. ${ }^{144}$ In addition, such individuals may not purchase the issuer's shares within three months of the date of their last sale (or vice versa). ${ }^{145}$

Article 16bis does not contain an explicit "anti-tipping" provision, nor does it address the question of tippee liability. While corporations are subject to the law if they own more than ten percent of the capital stock of an issuer, there are no provisions that expressly impose liability on corporations for insider trading violations by their employees or require corporations to adopt procedures designed to prevent insider trading by their employees. ${ }^{146}$

3. Enforcement. Violations of article 16 bis are treated as civil offenses. The CNV is authorized to conduct investigations of suspected violations of the statute and, if a breach is found, to impose administrative fines on violators. ${ }^{147}$ Before imposing any such fine, the CNV must first hold a hearing. ${ }^{148}$ Persons found to have misused privileged information are subject to fines of up to twice the amount of the gains obtained, plus interest, whereas persons found to have engaged in short-swing trading must disgorge their profits. 149 Individuals harmed by violations of article 16 bis are authorized to file a civil suit in the Mexican courts, with recovery limited to twice the amount of the insider's gains. ${ }^{150}$ A six-month statute of limitations applies to both the

141. The statute applies only to issuers whose securities are registered with the National Registry of Securities and Securities Brokers (the "National Registry"), a division of the Comision Nacional de Valores ("CNV"). All securities that will be publicly offered in Mexico must be registered with the National Registry. Overview of Mexico at $\$ 62.03$ [2] (cited in note 138).

142. SML art 16bis.

143. SML art 16 bis 1 .

144. Id.

145. Id art 16 bis 2 .

146. In addition to the SML, securities professionals are subject to the regulations of the Bolsa, which provide that brokers who engage in insider trading are subject to suspension from trading activities. See Mexican Stockbrokers To Be Prosecuted for Irregularities, Reuters Bus Rep (Feb 14, 1989).

147. SML art 16 bis 4.

148. Id art 16 bis 5 .

149. Id art 16bis 4. In the event that person is found to have engaged in short-swing trading but realized no profits, the statute authorizes the CNV to impose an alternative fine, in an amount equal to "200 to 3000 times the minimum daily wage in force in the Federal District, depending on the seriousness of the violation." Id.

150. Id. 
commencement of civil suits by private investors and the imposition of administrative fines by the CNV.151

Reports from Mexico suggest that insider trading remains widespread, in part because leading brokerage houses and listed companies share common control. ${ }^{152}$ Enforcement of the restrictions against insider trading, however, has been limited, at least in part due to a lack of surveillance mechanisms. ${ }^{153}$ Two recent developments provide evidence that Mexico plans to cure this deficiency. First, the Bolsa has acquired a computerized trading system from the Vancouver Stock Exchange, which provides electronic linkage between trading and surveillance functions. ${ }^{154}$ Second, the agreement signed between the CNV and the SEC in October $1990^{155}$ contemplates that the SEC will provide the CNV with technical assistance regarding, among other things, "systems necessary for effective market surveillance and enforcement programs." 156

IV

\section{Lessons From a Comparative Study}

A comparison of the law of insider trading in the United States and the statutes adopted in foreign countries yields several insights. Indeed, our analysis suggests that the United States has at least as much to learn from developments abroad as other nations can learn from the United States.

\section{A. Foreign Approaches}

Given their recent origin and ongoing revision, it is in some respects premature to criticize foreign insider trading laws. Nevertheless, two features of many of these initiatives are likely to impede their effectiveness. First, foreign statutes often fail to create substantial penalties for insider trading or to establish credible enforcement mechanisms. While it would be surprising

151. Id art 16 bis 6 .

152. For example, following the 1987 market crash, when the leading stock market index declined $74 \%$ over 28 trading days, the Ministry of Finance and Public Credit launched a sweeping investigation of Mexico's brokerage firms. The inquiry led to the indictment of four officials from two of Mexico's largest brokerage firms on charges of criminal violations of the SML. See Indictments in Mexico, NY Times D2 col 3 (Feb 20, 1989) (discussing indictment of Operadora de Bolsa SA officials). Although the principal allegation was that the defendants had misappropriated customers' funds and traded securities without their clients' consent, the case also focused attention on the powerful role played in Mexico by the leading brokerage houses and the routine access of these firms to inside information. See, for example, Tom Brown, Mexico's Free-Wheeling Stock Market Soars to New Heights, Reuters Bus Rep (May 15, 1991) (noting that leading Mexican brokerage houses and listed companies are frequently controlled by the same individuals, families, or business groups); Brook Farmer, Mexico Targets Stock Market Corruption, Christian Sci Mon 4 (Feb 16, 1989).

153. See, for example, Lori Hawkins, Mexico Faces Problems with Insider Trading, Reuters Canadian Fin Rep (May 16, 1991).

154. Mexico to Purchase Vancouver Stock Exchange Computerized Trading System, PR Newswire (July 22, 1991) (reporting that sale would take place on August 13, 1991).

155. Memorandum of Understanding Between the United States Securities and Exchange Commission and the Comision Nacional de Valores de Mexico On Consultation, Technical Assistance, and Mutual Assistance for the Exchange of Information (Oct 18, 1990).

156. Id at $\S 3(1)(x)$. 
if different countries acting independently established identical penalties or procedures for investigating suspected insider trading, minor sanctions and the failure to provide any government agency with significant investigatory powers suggest that some statutes are intended primarily for "window dressing." 157 . In addition, foreign statutes rarely impose secondary liability on corporations for insider trading by their employees or require companies to adopt procedures designed to prevent insider trading by persons they control or supervise. ${ }^{158}$ In comparison, recent amendments to the federal securities laws reflect Congress' conclusion that increasing the potential liability of employers for insider dealing by their employees is an effective means to discourage insider abuses.

\section{B. Lessons for the United States}

While criticisms of foreign insider trading laws are legitimate, the United States can also learn from recent developments abroad. First, the United States-in particular, Congress-should take note that other jurisdictions resolutely have undertaken the task of drafting, and then adopting, insider trading legislation. In comparison, the United States remains without a statutory definition of insider trading, with the contours of the law left to the federal courts to develop. As a result, not only traditional "corporate insiders," but also market professionals and other investors lack the specific guidance that a statutory definition of insider trading would provide. ${ }^{159}$ Under any circumstances, the ambiguities in this area of the federal securities laws would be unsettling. In today's international securities markets, however, such ambiguities are inexcusable.

The ability of foreign countries to define insider trading in clear and flexible terms belies oft-stated assertions in the United States that a legislative definition of insider trading would sharply curtail the SEC's ability to prosecute "evolving types of misconduct." 160 To the contrary, a statutory definition of insider trading would simplify the offense, as well as eliminate the SEC's need to rely upon Rule 10b-5 as its principal weapon against insider trading.

Unsuccessful attempts by the government to prosecute tippees for insider trading under Rule 10b-5 best illustrate the advantages of a statutory

157. Despite its other strengths, the EEC's insider Trading Directive does not address these concerns. Note, The Effects of the New EEC Draft Insider Trading Directive, 18 Ga J Intl \& Comp L 119, 140 (1988) (authored by Douglas A. Hystrom).

158. Note, A New Look at the European Economic Community Directive, 23 Vand J Transnatl L 135, 138, 169-72 (1990) (authored by Amy E. Stutz).

159. See Harvey L. Pitt \& Karen L. Shapiro, The Insider Trading Proscriptions Act of 1987: A Legislative Initiative for a Sorely Needed Clarification of the Law Against Insider Trading, 39 Ala L Rev 415, 417 (1988).

160. The Insider Trading Sanctions Act of 1983, Hearings before the Subcommittee on Securities of the Senate Committee on Banking, Housing, and Urban Affairs, 98th Cong, 2d Sess 37 (1984) (statement by John M. Fedders, former SEC Enforcement Division Director, that a statutory definition of insider trading was undesirable). 
definition of insider trading. In its decision in Dirks $v . S E C,{ }^{161}$ the Supreme Court held that the government must prove that a tipper communicated inside information to a tippee in return for a "personal gain" in order to hold either the tipper or the tippee liable under Rule 10b-5. Requiring a breach of fiduciary duty by the tipper, the Court reasoned that "[a]bsent some personal gain, there has been no breach of duty to stockholders." 162 This requirement has led the SEC to make detailed and intrusive allegations regarding personal relationships in order to establish that the tipper received a personal benefit. ${ }^{163}$ The inclusion of such allegations in a complaint, however, does not guarantee that the government will be able to prove that the disclosure of inside information breached a fiduciary duty, as recently demonstrated by the en banc decision of the Second Circuit in United States v. Chestman. ${ }^{164}$

In comparison, foreign statutes prohibit divulging inside information in broad terms and without reference to antiquated common-law fraud concepts, which are of limited relevance in an impersonal marketplace. For example, the EEC's insider Trading Directive provides that a person who possesses inside information and cannot trade himself shall not disclose that information to any third party, "unless such disclosure is made in the normal course of the exercise of his employment, profession or duties."165 This approach, which is vastly preferable, avoids the need to establish a breach of fiduciary duty or the "personal gain" to the tipper.

This article does not suggest that a statutory definition of insider trading is desirable simply because it might define the offense more broadly than have recent court decisions. Instead, the principal objective should be to provide

161. 463 US 646, 659 (1983).

162. Id at 662 .

163. See, for example, SEC v Thayer, [1983-1984 Transfer Binder] Fed Secur L Rptr (CCH) I 99,718 at 97,903 (SD NY Jan 5, 1984) (allegations of "personal private relationship" included in complaint to support claim that a tipper benefitted from trades by his mistress/tippee).

164. 947 F2d 551 (2d Cir 1991). The chain of information in Chestman started with Ira Waldbaum, who disclosed to his sister, Shirley Witkin, that the grocery store chain bearing his family name would be sold to the Greater Atlantic and Pacific Co. Witkin told her daughter, Shirley Loeb, who passed the information to her husband, Keith Loeb. After Keith Loeb advised Chestman, his broker, that "he had 'some definite, some accurate information' that Waldbaum was about to be sold at a 'substantially higher' price than its market value," Chestman purchased 11,000 shares of Waldbaum stock for his personal and customer accounts. Id at 555. The Second Circuit reversed Chestman's criminal conviction under Rule 10b-5. The court held that there was insufficient evidence that Keith Loeb had breached a "fiduciary-like relationship" with the Waldbaum family. Id at 570 . Absent a breach of fiduciary duty by Loeb, the court held, no basis existed to hold Chestman derivatively liable as Loeb's tippee or as an aider and abettor. Id at 571.

Ironically, the court upheld Chestman's conviction under Exchange Act Rule 14e-3, 17 CFR $\$ 240.14 \mathrm{e}-3$ (1992), which expressly prohibits any person in possession of material information relating to a tender offer which he or she knows or has reason to know has been acquired directly or indirectly from persons associated with the acquiring company or the target company from trading in the target company's securities (but does not require a breach of fiduciary duty). Chestman, 947 F2d at 556-63. Although Rule 14e-3 applies only in the context of a tender offer, the court's decision underscores the advantages of a statutory definition of insider trading from the government's perspective.

165. EEC Insider Trading Directive, art 3(a), Proposal for a Council Directive Coordinating Regulations on Insider Trading, 30 OJ Evr Comm (No C153) 8 (1987). 
clear guidance concerning the types of conduct that are forbidden. ${ }^{166}$ This objective could actually result in less expansive concepts of certain elements of the offense. ${ }^{167}$

Second, the adoption or enhancement of insider trading laws in foreign jurisdictions reflects well on the SEC's more cooperative approach to international enforcement matters in recent years. The Commission has largely abandoned a unilateral approach to transnational enforcement, in favor of closer cooperation with securities regulators in different countries. ${ }^{168}$ Much of the Commission's energies in this area have been directed toward the negotiation of MOUs with foreign governments, which establish procedures for the exchange of information in cases of suspected insider trading and other securities law violations.

Whether by design or by default, this process has improved the SEC's relations with foreign governments and regulators. As other countries identify areas of mutual interest with the United States while negotiating MOUs, they become more attuned to the justifications for prosecuting insider trading. Accordingly, there is a valuable lesson to be learned from the SEC's efforts: negotiation, while time consuming, ultimately proves a more effective means to secure the cooperation of foreign governments and financial institutions than strong-arm tactics in the federal courts.

\section{Compliance Issues in the New Era}

Most of the preceding discussion examined the insider trading laws of various jurisdictions on a nation-by-nation basis. In this section, the article addresses the cumulative impact of these laws on entities, such as multinational corporations and service firms, whose employees gain access to material, nonpublic information on a routine basis.

Not so long ago, employers had little reason to concern themselves with insider trading by their employees unless the transactions implicated the laws of the few countries, including the United States, that treated insider trading as an offense. As this logic no longer applies, employers that fail to evaluate the need for firm-wide restrictions on insider trading do so at their peril.

166. Although opponents of a statutory definition argue that litigation resolves uncertainties in the scope of insider trading liability, litigation is undeniably time-consuming as well as gut-wrenching to defendants. See Karl Groskaufmanis, The SEC's Enforcement Nose Dive, Legal Times 21 (Dec 16, 1991) (discussing vagaries of insider trading litigation under Rule 10b-5).

167. For example, other countries that have defined insider trading restrict the categories of information that may be deemed "material." See, for example, MOF Ordinance No 10 (Japan) (setting forth "matters considered to have an immaterial influence on the investment decisions of investors"). In comparison, any fact whose disclosure could be found to have "significantly altered the 'total mix' of information" available to a reasonable investor may be deemed "material" under the federal securities laws. TSC Industries $v$ Northway, Inc., 426 US 438, 449 (1976). Viewed in hindsight, however, many facts may satisfy this standard and result in liability. See, for example, $S E C$ $v$ Texas Gulf Sulphur Co. , 401 F2d 833, 849-52 (2d Cir 1968) (en banc) (rejecting lower court's holding that " 'the test for materiality must necessarily be a conservative one' " and holding that preliminary results from a core drilling were material).

168. See Pitt, Hardison \& Shapiro, Problems with Enforcement at 342-49 (cited in note 24). 
Assessing the appropriate response to the new regulatory environment requires employers to take into account a variety of practical and legal considerations. For example, employers should consider the damage to their reputations that might result if their employees were found-or even rumored-to have abused information entrusted to them in the course of their employment. Such factors become increasingly important as insider trading is viewed less tolerantly abroad and may lead employers to adopt firmwide restrictions even with respect to employees and securities transactions in countries where insider trading remains legal.

Determining whether employers may be exposed to liability if their employees engage in insider trading abroad requires a more careful assessment. In today's securities markets, more than one country may have an interest in the application of its laws to a particular case of insider trading. Jurisdiction and choice of law are not the only considerations, however; employers must also review the legal principles governing their secondary liability, if any, for insider trading by their employees. On balance, these factors should lead many. employers to conclude that firm-wide trading policies may be appropriate.

\section{A. Jurisdictional Scope of Insider Trading Laws}

In the current regulatory environment, it will prove harder to conclude that no nation will apply its insider trading laws to a specific transaction. The United States, in particular, takes a broad view of jurisdiction under the federal securities laws, premised on securities transactions and related activities conducted through the means of "interstate commerce."169 As one federal court has noted, these provisions frame a broad grant of jurisdiction, but "furnish no specific indication of when American federal courts have jurisdiction over securities law claims arising from extraterritorial transactions." 170 In a number of decisions over the past twenty years, however, federal courts have indicated that they generally will exercise jurisdiction over international securities transactions involving "significant conduct" or "significant effects" in the United States or some combination of conduct or effects in the United States.

In an insider trading case, a federal court clearly would assert jurisdiction under a "conduct" analysis if trades were executed on a United States

169. See, for example, Exchange Act $\$ 10,15$ USC $\S 78$ j (Supp II 1990).

170. Zoelsch $v$ Arthur Andersen $\xi^{\circ}$ Co., 824 F2d 27, 30 (DC Cir 1987). Although Exchange Act $\S 30$ (b) provides that the Act shall not apply "to any person insofar as he transacts a business in securities without the jurisdiction of the United States," this provision has been narrowly interpreted as applying only to entities, such as broker-dealers, that conduct an ongoing securities business. See, for example, Schoenbaum v Firstbrook, 405 F2d 200, 208 (2d Cir 1968), partially rev'd on other grounds, $405 \mathrm{~F} 2 \mathrm{~d} 215$ (1968) (en banc). In addition, the courts have interpreted the phrase "without the jurisdiction of the United States" to refer to the jurisdictional limits of the federal courts, rather than to the geographical boundaries of the United States. Bersch v Drexel Firestone, Inc., 389 F Supp 446, 458-59 (SD NY 1974), aff'd in part and rev'd in part on other grounds, 519 F2d 974 (2d Cir 1975). 
securities market. ${ }^{171}$ Other conduct in the United States that has been deemed sufficient to support the exercise of jurisdiction over securities transactions includes the use of the United States mails or telephones ${ }^{172}$ and the transfer of funds into or out of the United States. ${ }^{173}$ In addition, meetings in the United States during which material, nonpublic information was disclosed might also support a finding of jurisdiction, particularly in a lawsuit brought by the SEC or by United States residents. ${ }^{174}$ Under an "effects" test, U.S. courts have exercised jurisdiction, under federal securities laws, over transactions executed on foreign exchanges that had a significant impact on United States markets. ${ }^{175}$

Accordingly, employers must be sensitive to the broad reach of the securities laws of the United States. Moreover, other foreign countries that prohibit insider trading might also assert jurisdiction over a particular transaction. In the past, foreign countries have often limited jurisdiction under their securities laws to transactions executed on domestic exchanges. ${ }^{176}$ Other countries, however, have recently adopted broader jurisdictional provisions which resemble the "conduct" and "effects" tests employed in the United States. ${ }^{177}$ The variety in the jurisdictional scope of different laws only further confounds the effort to predict the number of countries that might assert jurisdiction over a specific transaction.

\section{B. Secondary Liability}

Employers should also evaluate their potential secondary liability for insider trading by their employees. As is true with respect to the exercise of jurisdiction, the scope of secondary liability is broader in the United States than in most countries; nonetheless, employers should anticipate heightened liability abroad for insider trading violations by their employees in the future.

Under the federal securities laws of the United States, courts may impose secondary liability on employers for insider trading by their employees based

171. See, for example, SEC v Tome, 638 F Supp 596, 600-01, 608 (SD NY 1986).

172. See, for example, SEC v Gulf Intercontinental Finance Corp., 223 F Supp 987, 995 (SD Fla 1963).

173. See, for example, SEC v Banca Della Svizzera Italiana, 92 FRD 111, 118 (SD NY 1981).

174. See, for example, Leasco Data Processing Equip. Corp. v Maxwell, 468 F2d 1326 (2d Cir 1972).

175. See, for example, Schoenbaum, 405 F2d at 206 (U.S. court asserted jurisdiction under $\$ 10$ (b) of the Exchange Act and Rule 10b-5 thereunder against Canadian company, the stock of which was traded on the Toronto and American Stock Exchanges, where allegedly fraudulent acts in Canada caused the stock's value to decline on the U.S. exchange). On the other hand, federal courts have declined to exercise jurisdiction where the conduct abroad results in only "generalized effects" in the United States. See, for example, IIT v Vencap, Ltd., 519 F2d 1001, 1016-18 (2d Cir 1975) (refusing to assert jurisdiction over fraudulent scheme abroad merely because some of alleged victims were U.S. citizens or residents); Bersch v Drexel Firestone, Inc., 519 F2d 974, 987-88 (2d Cir 1975) (sale by offshore mutual fund of Canadian securities held in its portfolio had insufficient impact on U.S. markets to warrant exercise of jurisdiction).

176. See, for example, SML art 16bis (Mexico).

177. See, for example, Corporations Law $\$ 1002$ (Australia) (insider trading law applies to (a) acts or omissions within Australia relating to the securities of any corporation, whether the corporation was formed or does business in Australia and (b) acts or omissions outside Australia relating to the securities of any corporation which was formed or does business in Australia); Criminal Code (Netherlands) art 336a(2) (restrictions on insider trading apply to persons who effect securities transactions from within the Netherlands on foreign exchanges). 
on common-law principles of respondeat superior or aiding and abetting, as well as under the "controlling person" provisions of the Exchange Act. ${ }^{178}$ In addition, pursuant to recent amendments to the Exchange Act, ${ }^{179}$ controlling persons may face civil fines for their employees' insider trading, in an amount not to exceed $\$ 1$ million per violation, or three times the amount of the profit gained or the loss avoided as a result of the violation. While, as a practical matter, controlling person liability is unlikely to be imposed on employersother than registered broker-dealers and investment advisers-without notice that their employees are engaged, or about to engage, in illegal conduct, these provisions create a strong incentive for firms to evaluate the need for procedures restricting trading by their employees.

In comparison, the countries surveyed in Part III either limit secondary liability or do not expressly subject employers to liability for insider trading by their employees. ${ }^{180}$ Indeed, the absence of such provisions has been one of the principal criticisms of foreign insider trading laws. In evaluating the need for appropriate procedures, however, employers should assume that some countries will amend their insider trading laws in the future to provide for some form of "controlling person" liability. ${ }^{181}$

\section{Development of Firm-Wide Policies}

The potentially broad application of insider trading laws and the prospect of heightened vicarious liability should lead many employers to consider restrictions on trading by employees. ${ }^{182}$ The adoption of such policies will

178. See Exchange Act $\S 20(a), 15$ USC $\$ 78 t(a)$ (1988).

179. See Insider Trading and Securities Fraud Enforcement Act of $1988 \S 3(\mathrm{a})$, Pub L No 100 704,102 Stat 4677, 4677-78 (adding new $\$ 21$ A to the Exchange Act) ("ITSFEA"). An employer is a "controlling person" for purposes of $\$ 21 \mathrm{~A}$. Report of the House Committee on Energy and Commerce, HR Rep No 910 , 100th Cong, 2d Sess 17, reprinted in 7 USCCAN 6043, 6054 (1988) (ITSFEA was intended to "increase the economic incentive for [employers] to supervise vigorously their employees").

Section 20(a) of the Exchange Act does not apply to the civil fines authorized by $\$ 21 \mathrm{~A}$. Rather, to impose fines on employers as controlling persons under this section, the SEC must establish that the controlling person either (1) knew or recklessly disregarded the fact that the controlled person was likely to engage in insider trading and failed to take "appropriate steps" to prevent such conduct; or (2) in the case of broker-dealers or investment advisers registered with the SEC, knowingly or recklessly failed to establish, maintain, or enforce procedures reasonably designed to prevent the misuse of material, nonpublic information, and such failure substantially contributed to or permitted the violation.

180. In Japan, employers whose employees engage in insider trading are subject to fines under SEL art 207, whereas in Australia corporations are charged with knowledge of information in the possession of their employees and, therefore, violate the law directly if they engage in prohibited transactions. See Corporations Law $\S 1002 E$. Australia does not, however, currently impose liability on employers for insider trading by their employees, nor do France, Germany, or Mexico.

181. This could occur either through adoption of specific statutory provisions imposing derivative liability or application of traditional agency principles to hold employers liable for the conduct of their employees.

182. In the authors' experience, many employers, such as multinational corporations and service firms, have trading policies with respect to their United States-based employees and operations. Such policies, however, may not be enforced with respect to foreign-based employees, based on an assumption that they were intended to apply primarily in the United States.

Under the federal securities laws of the United States, registered broker-dealers and investment advisers are required to "establish, maintain, and enforce written policies and procedures reasonably 
not insulate an employer from liability for wrongful conduct by its employees. At a minimum, however, they provide guidance to employees who seek to comply with fast-changing legal requirements.

A program designed to reduce the risk of insider trading by employees and an employer's liability for its employees' transactions might include some combination of the following elements: (1) restrictions on access to inside information within the company; ${ }^{183}$ (2) restrictions on securities transactions; 184 (3) pre-clearance of trades by the employer; 185 (4) restrictions on short-term trading; 186 (5) affirmations of compliance by employees with company policies; ${ }^{187}$ and (6) training sessions. ${ }^{188}$ Each employer must decide what, if any, guidelines and restrictions on trading by its employees are appropriate, taking into account the sensibilities of its employees in different locations.

\section{VI}

\section{ConCLusion}

Insider trading was once viewed as a concern, if not a problem, unique to the United States. The adoption and enhancement of foreign insider trading laws in recent years demonstrates otherwise. While no other country has demonstrated the same commitment as the United States to the investigation and prosecution of insider trading, developments abroad reflect the growing international consensus that insider trading is inconsistent with basic principles of fair dealing and should not only be discouraged, but punished.

designed . . . to prevent the misuse . . of material, nonpublic information . . . Exchange Act $\S 15(\mathrm{f}), 15$ USCA $\S 780(\mathrm{f})$ (1991); Investment Advisers Act of 1940 \$ 204A, 15 USCS $\$ 80 \mathrm{~b}-4 \mathrm{~A}$ (1991). While other employers are not expressly required to adopt such policies and procedures, failure to do so may nevertheless increase their potential secondary liability.

183. For example, an employer might restrict access by employees to files likely to contain inside information, require the use of code names for sensitive projects, and adopt procedures governing the creation, maintenance, and destruction of confidential documents.

184. An employer may bar its employees from trading in the company's securities, as well as the securities of companies with which the employer does business, in order to avoid the potential appearance of impropriety. As an alternative, some companies have adopted internal "codes of conduct," which provide that no employee may trade in securities while in possession of material, nonpublic information obtained during the course of his or her employment.

185. Firms that routinely obtain access to material, nonpublic information often require employees (and other members of their households) who intend to engage in securities transactions to affirm that they do not possess any material, nonpublic information regarding the issuer. While a pre-clearance requirement imposes a substantial administrative burden on an employer, it demonstrates the employer's good-faith effort to monitor securities transactions by persons entrusted with confidential information.

186. Many employers discourage employees from engaging in short-term trading-purchasing and selling securities within less than a 12-month period-since "in-and-out" trading is often characteristic of insider trading and is, therefore, more likely to attract the attention of regulatory authorities.

187. Employers that adopt procedures on securities trading generally require their employees to affirm their understanding of-and compliance with-such procedures when hired, and on a regular basis thereafter.

188. In addition to meeting with new employees, employers should hold periodic sessions to emphasize legal restrictions on insider trading, as well as ethical and business considerations that may require adherence to standards beyond those mandated by law. 
